\title{
Nature Notes from Spruce Dale Farm
}

\author{
By C. Stuart Francis, Torch River
}

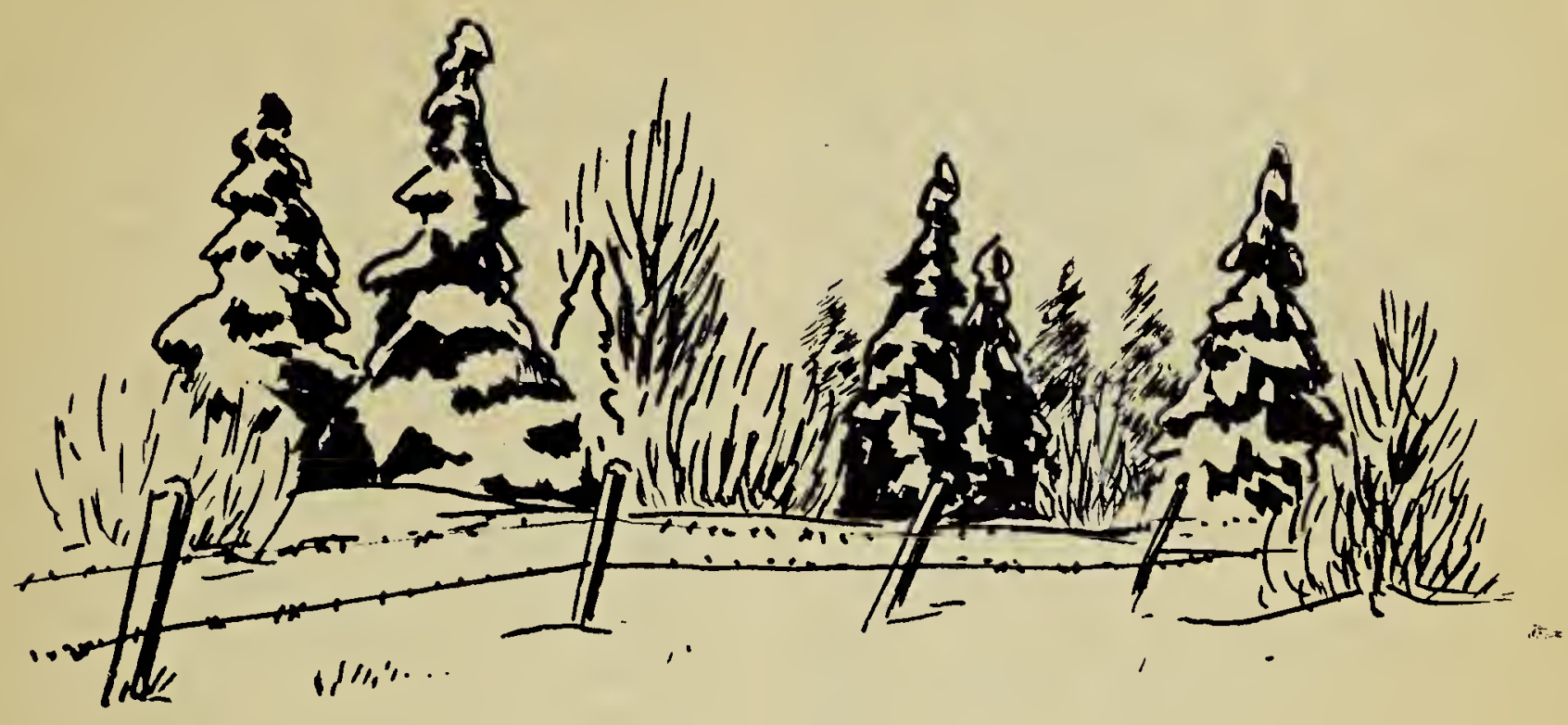

Here are a few unusual notes of fur and feather which have come to my attention during this past year.

Last winter my son, Stanley, was working along the Flin Flon Highway northeast of White Fox cruising timber, and one day while he was waiting for a truck to pick him up along the highway, a Gray Jay or "Whiskey Jack," as they are known here in the north, visited him while he was eating his lunch. Stanley noticed that the jay had a porcupine's quill sticking right through its neck. Possibly the quill got stuck there while the jay was feeding on a dead porky somewhere, but it did not seem to bother it any.

We are building a new house at Spruce Dale Farm and one day late this fall when we were all busy with hammer and saw, making lots of noise, who should show up but a Great Gray Owl. He sat on a twenty-five foot spruce not more than 100 feet from us for several hours, and all the noise did not seem to bother him in the least. Great Gray Owls seem to be showing up more each year now.

Last July when we were travelling by outboard motorboat the full length of Little Bear Lake, which is about $11 \frac{1}{2}$ miles across at the widest point with several "narrows" sometimes 150 yards or less, we were passing through one of these narrows with a light breeze making some fair waves of possibly six inches high, when I spied a Red Squirrel swimming lustily in front of the boat. He was crossing to the opposite side of the lake and he surely looked pretty small with only his head and bushy tail appearing out of the water. Possibly he had made the trip before.

I have lately received a report that a Gray Squirrel was shot 16-18 miles northeast of Nipawin. The Gray Squirrel (Sciurus carolinensis) is regarded as a southern species, but apparently quite a number of animals from south of the border are beginning to make their appearance in Saskatchewan. A record of the Gray squirrel at Rose Valley is the nearest record to us given by Harvey Beck in his Guide to Saskatchewan Mammals (1958). This squirrel is considered to be one of the most graceful and handsome of the whole squirrel family.

Let's keep our eyes and ears open this year, and who knows what unusual happenings in nature we shall uncover. 